\title{
Design and Implementation of Green Construction Scheme for a High-rise Residential Building Project
}

\author{
Yong Zhou ${ }^{1, *}$, You Zhen Huang ${ }^{1}$ \\ ${ }^{1}$ School of Architecture, Huang Gang Normal University, 438000 Huang Gang, Hubei, China
}

\begin{abstract}
This paper mainly studies the green construction scheme of a high-rise residential building project. From "four sections one environmental protection", saving material, water saving, energy saving, economical use of land and environmental protection conduct analysis and research. Adopting scientific, advanced, reasonable and economical construction technology measures, implementing green construction method. Promoting energy-saving technologies in buildings, ensuring the sustainable use of resources, Maximum savings of resources and energy, increase energy efficiency, to reduce pollution, reducing the adverse environmental impact of construction activities, ensure construction safety, build sustainable buildings.
\end{abstract}

\section{Introduction}

A high-rise residential building project is 36 stories, the floor area is 3686.68 square meters. It consists of two parts: the aboveground house and the underground garage. The underground garage (including the civil defense project) has a total height of $5.1 \mathrm{~m}$. The height of the main building is $109.9 \mathrm{~m}$, the total construction area is 14286 square meters. The basic structure of the project is a pile raft. The diameter of the pile is $600 \mathrm{~mm}$, the pile end holding layer is silty clay layer. The main structure form is reinforced concrete shear wall, the seismic fortification intensity of the project is 7 degrees. The seismic grade is level 2. The environment category of the concrete structure on the ground is class I, underground part of the concrete structure environment categories III class.

Considering that the construction period of the project is relatively tight, the construction period of the project is relatively long. There are many construction during the winter rain. The requirements for civilized construction, environmental protection and safety are very high. The aim of this project is to create "provincial quality project", "municipal civilized construction site" and "bureau observation site", to meet the requirements of "four sections, environmental protection and occupational health and safety" as stipulated by the relevant national standards, to meet the requirements of owners and social welfare to the maximum extent. According to GB/T50905-2014, Green construction code for construction projects, GB50325-2010 (2013), the standard of indoor environmental pollution control of civil construction engineering, (GB/T50378-2006), green building evaluation standard, GB/T50640-2010, evaluation criteria for green construction of construction projects, GB50411-2007, Specification for acceptance of construction quality of building energy conservation projects, GB12523-2011, emission standard of environment noise for boundary of construction site. Indoor air quality standards GB/T18883-2016, and the bidding documents for the general project contracting project, tenders, construction contracts and related annexes, tenders, construction contracts and related annexes, special plan for this green construction.

\section{Text}

Green construction is refers to engineering construction, under the premise of ensuring quality, safety and other basic requirements, through scientific management and technological progress, minimize saving resource, reducing construction activities that adversely affect the environment. Realize "four sections of environmental protection", saving material, water saving, energy saving, economical use of land and environmental protection and so on. According to the bidding documents, construction contract and design drawings of the project, combined with the design of the construction organization and the actual conditions of the site and the main features of the project, fully consider the engineering quality and construction safety guarantee system, organization and management of engineering projects, layout of construction site, total construction schedule control and so on, we will formulate a special plan for green construction. The control items and targets of the green construction scheme are shown in table 1.

\footnotetext{
*Yong Zhou: 183337681@qq.com
} 
Table 1. Project green construction project control project and target.

\begin{tabular}{|c|c|c|}
\hline $\begin{array}{c}\text { Serial } \\
\text { number }\end{array}$ & Control project & Control objectives \\
\hline 1 & $\begin{array}{l}\text { Saving material } \\
\text { and material } \\
\text { resources } \\
\text { utilization }\end{array}$ & $\begin{array}{l}\text { The actual loss rate of } \\
\text { material is reduced by } \\
30 \%\end{array}$ \\
\hline 2 & $\begin{array}{l}\text { Water } \\
\text { conservation } \\
\text { and water } \\
\text { resources } \\
\text { utilization } \\
\end{array}$ & $\begin{array}{l}\text { The allocation ratio of } \\
\text { water-saving appliances } \\
\text { reached } 80 \% \text {, The actual } \\
\text { water consumption is } \\
\text { reduced by } 30 \%\end{array}$ \\
\hline 3 & $\begin{array}{l}\text { Energy } \\
\text { conservation } \\
\text { and energy } \\
\text { utilization }\end{array}$ & $\begin{array}{l}\text { Save } 10 \% \text { on actual } \\
\text { electricity consumption }\end{array}$ \\
\hline 4 & $\begin{array}{l}\text { Economical use } \\
\text { of land and } \\
\text { construction } \\
\text { land }\end{array}$ & $\begin{array}{l}\text { The effective utilization } \\
\text { ratio of temporary } \\
\text { facilities is greater than } \\
90 \%\end{array}$ \\
\hline 5 & $\begin{array}{l}\text { Environmental } \\
\text { protection }\end{array}$ & $\begin{array}{l}\text { Dust control, Noise } \\
\text { control, Light pollution } \\
\text { Control, Sewage control, } \\
\text { Construction waste } \\
\text { control }\end{array}$ \\
\hline
\end{tabular}

\subsection{Saving material and material resources utilization}

Saving material and material resources utilization, it is controlled mainly from five aspects, including economy of structural materials, economy of palisade materials, the economy of decorative materials and savings of working materials. All kinds of material saving in this project are shown in table 2 .

Table 2. Various materials saving control list of this project.

\begin{tabular}{|c|l|}
\hline Serial number & \multicolumn{1}{c|}{$\begin{array}{c}\text { Classification material } \\
\text { saving control }\end{array}$} \\
\hline 1 & Economy of structural materials \\
\hline 2 & Economy of palisade materials \\
\hline 3 & The economy of decorative materials \\
\hline 4 & Savings of working materials \\
\hline
\end{tabular}

Economy of structural materials, control steel scrap rate is less than $1.5 \%$, optimize the reinforcement plan, the rebar connection method adopts straight thread form, and use the reinforcement to process the excess tail material to make the lower horse stool, short support, etc. The template is made of aluminum alloy, which can save wood completely. Strengthen control over the quality of formwork. Avoid stitching between templates, the failure of the slurry and the support to strengthen the bulging mold, affecting the quality of concrete. Scientifically and reasonably arrange the concrete supply plan, implement active control, control and dynamic control, ensure the concrete saving rate of concrete is greater than $3 \%$.
Economy of palisade materials, to strengthen the management of the transportation, stacking, transshipment and custody of the surrounding materials such as bricks and blocks, pay attention to the light, prevent damage. Before masonry walls, first, try to arrange the dry brick (block), reasonably determine the formation and thickness of dry brick (block). It is strictly forbidden to cut bricks at random during the masonry process. Avoid using whole bricks less than $1 / 3$ of length to avoid wasting material. For aerated concrete blocks must be cut by cutting machine, to reduce the damage to the remaining bricks. Using pre-mixed mortar technology, reduce the waste of mortar.

The economy of decorative materials. Make overall arrangement before construction, for large decorative blocks, it can be pre-arranged, minimize the use of nonmonolithic materials. The order of interior decoration construction, should be strictly according to the first canopy, then metope, finally ground, organize construction from top to bottom. Avoid improper contamination or damage to the veneer due to process arrangement. For paint, latex paint and other liquid decorative materials, should be based on the amount of each shift and the actual demand of the working face, using a separate barrel for use, ensure that the day or shift is used up, avoid material deterioration or cross contamination after opening. Various semi-finished products used in construction, such as stone, glass and wood decorative components, the construction project department shall be responsible for providing specific dimensions, the supplier shall process the products according to relevant standards and requirements.

Savings of working materials. The annual loss rate of the steel tubes used to strictly control scaffolds and scaffolds is within $1 \%$. The annual loss rate of connection coupler is less than $2 \%$. To protect the entrance, guard rail, enclosure, step Angle, etc. We should make full use of the remaining waste templates and wood beams, take recycling. For structures full of scaffolding, it is best to use a button-down scaffold with a combination of pipe fittings. The main keel is adopted to shape the back and shape lock system, the secondary keel adopts galvanized small square steel, reduce the construction turnover material to the wooden side a lot of use.

\subsection{Water conservation and water resources utilization}

Water conservation and water resource control include water management, recycling water, secondary use of water resources, water-saving systems and water-saving appliances, collection and utilization of unconventional water sources, etc. Rational determination of water conservation and water resources control objectives, ensure that the reuse of non-traditional water sources and recycled water is greater than $30 \%$. Municipal water saving rate is greater than $10 \%$. The water supply system of construction site is arranged according to living area and production area respectively. The living area water pipe network is the PPR pipe hot melt connection, the 
director diameter is $50 \mathrm{~mm}$, the diameter of the branch pipe is $25 \mathrm{~mm}$. half ball valve faucet is set at the end of each branch pipe. Setting up rainwater sedimentation tank outside the construction site, and set the water gun, the rainwater collection is used for secondary recycling. Construction site equipment, equipment, vehicle washing water set up circulating water device. Watersaving systems and water-saving appliances are adopted in the construction site and living areas. Improve the allocation ratio of water-saving appliances. Water saving products should be used for temporary projects. Install metering device, adopt specific water-saving measures. Using a fire pool or sedimentation tank, collecting rainwater and surface water, used for construction and production of water. Site equipment, equipment, vehicle washing, spray the road, greening and irrigation water, preferential use of unconventional water sources, try not to use municipal tap water. The water supply pipe network should be designed according to the water consumption, reasonable diameter, the pipeline is simple, take effective measures, reduce leakage of pipe network and water equipment.

\subsection{Energy conservation and energy utilization}

Energy conservation and energy utilization is mainly controlled from three sub-items, such as machinery and equipment and production, living and office temporary facilities and construction electricity and lighting.

Energy saving measures for machinery and equipment, to ensure the low consumption, efficiency and safety of mechanical equipment, the completion rate of mechanical equipment is $100 \%$. The maintenance of construction machinery and equipment must be done in time. The power of the construction machinery is required to match the load. The electromechanical installation project should adopt the energy-saving mechanical equipment such as low energy consumption, high efficiency inverter type welding machine and handheld power tool. For the site construction tower crane, construction elevators, searchlights, welding machines and other mechanical equipment of the electricity metering, it should be a machine that sets a single meter, the meter is measured separately.

Energy-saving control measures for production, living and office temporary facilities, living and office temporary facilities, site production, life temporary housing layout to the south and north, in a zigzag pattern, to obtain good lighting and ventilation effect. The wall, roof and other surrounding materials should adopt energy-saving and heat-insulating materials. The office layout is reasonable and orderly. Living areas are heated by bio-fuel boilers, the heating equipment is provided by the manufacturer, demand the economy beautiful and practical. In the field construction project department and construction team to carry out a wide range of energy saving assessment, strengthen the staff to save electricity consciousness. For the living area, the electricity shall be measured separately. Statistical power consumption, and comparative analysis. The canteen should also be measured separately, special statistics canteen USES electricity.

Energy saving measures for construction electricity and lighting, in addition to the lighting fixtures used during nighttime construction, the utilization rate of energy-saving lamps in the field is $100 \%$. For offices, dormitories and other indoor lighting power density value control in the $5 \mathrm{w} / \mathrm{m}^{2}$, the basement construction area and other special lighting power density value control in the $4 \mathrm{w} / \mathrm{m}^{2}$. Temporary building lighting in office area and living area is illuminated by fluorescent lamps. Set up the "save electricity" sign in an eyecatching indoor location. Indoor lamps are controlled by each switch with no more than 2 lamps. The construction process can be arranged reasonably, avoid using highpower equipment at the same time, to reduce the peak effect of power load.

\subsection{Economical use of land and construction land}

According to the site conditions and the actual needs of the project, the temporary construction should be reasonably arranged. The floor area of all kinds of temporary buildings should be controlled according to the minimum area of land use index. The control index of construction land rate of unit construction area is $25 \%$. Optimizing the construction plan of deep foundation pit, control the width of the soil in the foundation pit, minimize excavation and backfill of earthwork, protect the surrounding natural environment. Construction site warehouse, material storage yard, rebar processing room, work shed and other layout, should be near the temporary road, reduce transport distance. The temporary office and living room adopt the standardized prefabricated structure, such as double deck light steel activity board room. Site area as much as possible using ground greening, reduce site hardening area.

\subsection{Environmental protection control measures}

Environmental protection control measures include dust control, noise and vibration control, light pollution control, water pollution control and construction waste control.

Dust control measures. During the construction phase of earthwork, must control the construction site visual dust height less than $1.5 \mathrm{~m}$, and it cannot spread beyond the construction site. In the stage of construction, installation and decoration, it is necessary to control the site of the operation area to measure the dust height less than $0.5 \mathrm{~m}$. The difference between the average concentration of the total suspended particulates (TSP) and the urban background value of the total suspended particulates (TSP) measured in the surrounding area of the construction site must be less than $0.08 \mathrm{mg} / \mathrm{m} 3$. There is no dust in the area, such as office area, living area, parking lot and activity area. The construction area is arranged into a circular road. The hardened pavement is not less than $6 \mathrm{~m}$ wide. The driving speed of the construction site should be controlled, the speed limit is 
$5 \mathrm{~km} / \mathrm{h}$. In addition to the hardening part of the construction site, the rest of the ground should be green, reduce dust pollution. Construction waste is sealed in bags, Effective prevention of dust pollution during transportation. For bagged powder materials such as cement, gypsum powder, putty powder, etc. sealed warehouse and sealed container shall be set on site. Handle with light in loading and unloading, dust can be avoided.

Noise and vibration control measures. Reasonable selection of construction machinery for noise and vibration, such as pile driver, forklift, excavator, dump truck, vibration machine, etc. Reasonable arrangement of mechanical time, ensure the smooth and efficient operation of mechanical construction. Vehicles are prohibited from honking in the field. Measure and control the noise level of the field every day. The wood processing shed around the site should be boarded up. When concrete is poured, there are no vibration bars, collision bars or templates. The concrete after pouring belt, construction joint, structural expansion die and so on, try to use artificial methods, minimize the use of mechanical equipment such as pneumatic picks. Reference to national standard GB12523-2011 environmental noise emission standards for construction field, the noise control limit for each construction stage of the project is shown in table 3 .

Table 3 Noise control table for each construction stage of this project.

\begin{tabular}{|c|c|c|}
\hline $\begin{array}{c}\text { The construction } \\
\text { phase }\end{array}$ & $\begin{array}{c}\text { Daytime noise } \\
\text { limit (unit: fb) }\end{array}$ & $\begin{array}{c}\text { Night noise } \\
\text { limit (unit: fb) }\end{array}$ \\
\hline $\begin{array}{c}\text { Earthwork } \\
\text { construction }\end{array}$ & 65 & 55 \\
\hline $\begin{array}{c}\text { Pile foundation } \\
\text { construction }\end{array}$ & 80 & $\begin{array}{c}\text { Ban on the } \\
\text { construction }\end{array}$ \\
\hline $\begin{array}{c}\text { Structure } \\
\text { construction }\end{array}$ & 65 & 55 \\
\hline $\begin{array}{c}\text { Decorate } \\
\text { construction }\end{array}$ & 55 & 50 \\
\hline
\end{tabular}

Light pollution control measures. For light intensity of night light lamps and lanterns should set hood. In the field of welding construction, special shade cloth is used to cover the area, set a fire fighting position at the lower part of the weld. In the flash butt welding machine field operation, except for the artificial side, the remaining three sides are closed with waste templates. For office area, living area night outdoor lighting all USES energysaving lamps and lanterns.

Water pollution control measures. One septic tank is set up in the living area and office area respectively, set up a grease trap. The septic tank is cleaned by the professional cleaning department once a month. The grease trap is cleaned by the professional cleaning department once a month. To discharge water quality on site, each month, the relevant departments conduct a test. The site antifreeze and equipment lubricating oil are placed on the special shelf of the warehouse, to avoid spills and pollution.
Construction waste control measures. This project controls less than 400 tons of construction waste per 10,000 square meters. Solid waste includes concrete slags, block edges, brick edges and so on, and the reuse rate is not less than $30 \%$. The recycling rate of ground ash is not less than $70 \%$. The construction waste is classified and stacked, classification process. Close storage of toxic and hazardous waste. At the site construction waste recycling station, construction of a simple solid waste treatment plant, the part of the solid waste to take classification recycling, separate organic matter removal and fragmentation treatment. And then I'm going to put it in, it can be use again. To advance the design of the sub-item of the fine decoration division, as far as possible to reduce the masonry material, floor tile and ceiling board materials such as the use of non block, control produces more waste and garbage.

\section{Conclusion}

Through the planning and implementation of the green construction scheme of this project, mainly includes "four sections one environmental protection", saving material, water saving, energy saving, economical use of land and environmental protection and so on. Adopting scientific, advanced, reasonable and economical construction technology measures, implementing green construction method, implementing green construction management. Promoting energy-saving technologies in buildings, ensuring the sustainable use of resources, build sustainable buildings. Maximum savings of resources and energy, increase energy efficiency, to reduce pollution, reducing the adverse environmental impact of construction activities, ensure construction safety, realize harmonious development with nature and society Achieve high quality, high efficiency, safety, civilization, low consumption and other green construction targets.

\section{References}

1. Wang Y. To explore the application of green construction technology in construction engineering $[\mathrm{J}]$. Green Environmental Protection Building Materials, 222-225, 1 (2018)

2. Li Y S. Application of green construction technology in high-rise building construction [J]. Housing and Real Estate, 179-183, 12 (2017)

3. $\mathrm{Xu}$ B. Construction of green construction technology and its application research [J]. Chinese \& Overseas Architecture, 157-160, 12 (2017)

4. Wang H B, Bao Z M, Wang W Z. The present situation of green construction technology of domestic construction engineering $[\mathrm{J}]$. Soil Engineering and Foundation, 490-494, 4 (2017)

5. Zhu X X. Quality control study of housing construction $[\mathrm{J}]$. China Building Materials Technology, 78-80, 2(2016) 
6. Liu A F. To resolve the quality control of industrial and civil construction projects [J]. Low Carbon World, 166-167, 1 (2017)

7. Wang C X. Research on the quality control measures of construction projects $[\mathrm{J}]$. Jiangxi Building Materials, 78, 4 (2016)

8. Zhang S F. Building project quality control in the whole process analysis [J]. Manager' Journal, 293, 11 (2013)

9. Live D H. Series the building project construction process quality control [J]. Manager' Journal, 93, 9 (2010)

10. Chen F. How to control the whole process of construction quality [J]. Friend of Science Amateurs, 76-77, 5 (2010)

11. Goo R. Building engineering construction whole process quality management research [J]. Industrial C, 7, 23 (2015)

12. Chen B. Building engineering construction quality management and control [J]. Guangdong Science and Technology, 44-45, 15 (2012)

13. Wei W D Shallow theory of construction engineering project construction phase quality control key [J]. The High-quality Goods, 45-46, 2 (2016)

14. Liao $\mathrm{H}$. Introduction to the construction of engineering quality control [J]. The Green Building, 62-64, 3 (2014)

15. $\mathrm{Yu} \mathrm{L} \mathrm{J.} \mathrm{Introduction} \mathrm{to} \mathrm{the} \mathrm{quality} \mathrm{control} \mathrm{of}$ construction engineering construction stage [J]. Architecture and Budget, 28-30, 4 (2014)

16. [16. GB. 50325-2010 (2013), Standard of indoor environmental pollution control for civil construction projects [S]. Beijing: China Planning Press, (2010)

17. GB/T50905-2014, Green construction code for construction projects [S]. Beijing: China Construction Industry Press, (2014)

18. GB12523-2011, Emission standard of environment noise for boundary of construction site [S]. Beijing: China Construction Industry Press, (2011) 